\title{
Jak budynki nas ,zaskakują" Renowacja Alte Aula w Wiedniu ${ }^{1}$
}

\author{
Albena Yaneva \\ University of Manchester, UK \\ Przekład i opracowanie Ewa Bińczyk, Krzysztof Tarkowski \\ Przekład otrzymano 8 lutego 2018, zaakceptowano 22 lutego 2018, opublikowano zimą 2018/2019.
}

\begin{abstract}
Abstrakt
Zarówno konserwatorzy, jak i modernizatorzy chcieliby przemawiać w imieniu dawnych budowli podczas dyskusji nad ich konserwacją oraz renowacją. Jednak w wielu przypadkach ignorują oni sprawczość budynków, nie uwzględniając różnorodności innych bytów wprawionych w ruch na scenie renowacji i konserwacji. Podliczając aktorów ludzkich i pozaludzkich uczestniczących w renowacji Alte Aula w Wiedniu, zajęłam się dynamiką tego procesu. Analizowałam bogactwo repertuaru działań budynku: jego uległość, posłuszeństwo, sprzeciw oraz opór.
\end{abstract}

Słowa kluczowe: renowacja; etnografia; sprawczość budynków; ANT; architektura.

\section{Budynki w perspektywie studiów nad nauką i technologią (STS)}

W ciągu ostatnich dziesięciu lat studia nad nauką i technologią oraz studia nad miastami zaangażowane były w stymulującą wymianę idei, która doprowadziła do fascynujących debat, owocnych dla obu tych dziedzin (Mukerji, 1997; Aibar, Bijker 1997; Galison, Thompson 1999; Picon, Ponte, Lerner 2003; Livingston 2003; Hommels, 2005; Gieryn, 2002). Twierdząc, że jest czymś zaskakującym, iż budynki tak rzadko były dotąd przedmiotem dociekań socjologów, Gieryn $(1999,2002)$ przeprowadził serię badań budynków instytucji naukowych i analizował relacje między jakością przestrzeni a tożsamością nauki

\footnotetext{
${ }^{1}$ Źródło: How Buildings 'Surprise'. The Renovation of the Alte Aula in Vienna. „Science Studies” 2008, Vol. 21, No. 1: 8-28. Redaktorzy numeru dziękują Panu Wojciechowi Bagińskiemu z Muzeum Pałacu Króla Jana III w Wilanowie za zwrócenie uwagi na ten tekst.
} 
i jakością badań naukowych, między zasadami projektowania a przebiegiem projektowania, uwzględniając przy tym różnych uczestników procesu projektowego oraz ich strategie negocjacyjne (Gieryn, 1999). Chodziło o to, żeby wzbogacić dotychczasowe odczytywanie post hoc ukończonych już budynków o oparty na wywiadach i archiwaliach opis procesu ich projektowania. Używając przede wszystkim narzędzi pojęciowych konstruktywistycznych studiów nad technologią do analizy budynków po-fakcie ich skonstruowania, a nie podczas procesu projektowania, wspomniane prace rozpatrywały projektowanie i planowanie jako rodzaj technologii, uznając budynki za socjotechniczne artefakty. Jak się jednak wydaje, zignorowano szczególnie istotne zagadnienie: problem rzeczywistej dynamiki procesu projektowania w wymiarze materialnym, poznawczym oraz kulturowym. Warto przy tym dodać, że w badaniach nad samym procesem projektowania rzadko bierze się pod uwagę praktyki mające na celu adaptację budynków, ich konserwację, naprawę, przeprojektowywanie, rozbudowywanie czy remontowanie (Brand, 1994; Graham, Trift, 2007).

Ostatnie badania w obrębie STS interpretowały praktykę projektantów-inżynierów w taki sam sposób, jak studia nad nauką ujmowały praktykę naukowców ${ }^{2}$. Podkreślając złożoną społeczną dynamikę procesu projektowania ${ }^{3}$, studia te umożliwiły lepsze zrozumienie praktyk wizualizacyjnych, narzędzi, komunikacji i środowiska projektowego, jak również znaczenia rozproszonego poznania ${ }^{4}$ i kultury materialnej w pracy inżynierów. W obszarze badań nad praktyką architektów z perspektywy STS ciągle jednak pozostaje wiele do zrobienia. Studia nad nauką i technologią przechodzą dość obojętnie obok architektów i urbanistów, a także ich pracy w studiach projektowych, warsztatach modelarskich, na salach konferencyjnych czy placach budowy. W serii swoich programowych artykułów Michel Callon podkreślał znaczenie perspektywy Teorii Aktora-Sieci (ANT) dla rozumienia koncepcji architektonicznych skoncentrowanych na wymiarze materialnym projektu, utożsamianym z bogactwem schematów i planów wizualizacyjnych, stabilizowanych podczas negocjacji (Callon, 1996). Nie poszły za tym jednak żadne szczegółowe badania praktyk architektonicznych prowadzone z perspektywy ANT. Wyjątek stanowią badania praktyki projektantów holenderskich i japońskich, wykorzystujące ANT po to, by rzucić nieco więcej światła na następujące po sobie działania projektowania i wizualizacji w biurach Rema Koolhaasa (Yaneva, 2005) i Kengo Kumy (Houdart, 2006). Program Callona spotkał się z krytyką różnego typu ze strony teoretyków praktyki architektonicznej (Raynaud, 2001). Nie zaproponowano jednak żadnych empirycznych alternatyw, choć zainteresowanie logistyką projektów architektonicznych wzrosło (Bonnet, 1999) i zawsze była ona przedmiotem namysłu tradycyjnej socjologii skupionej na zawodzie architekt (Champy, 2001). W krajach anglosaskich również stosowano bardziej tradycyjne podejścia socjologiczne

\footnotetext{
${ }^{2}$ Zob. Latour, Woolgar, 1979; Lynch, 1985; Knorr-Cetina, 1999.

${ }^{3}$ Zob. Vincenti, 1990; Ferguson, 1992; Bucciarelli, 1993; Henderson, 1999; Vinck, 2003.

${ }^{4}$ Ang. distributed cognition - chodzi o koncepcję rozproszonego poznania wprowadzoną do STS przez Edwina Hutchinsa w książce Cognition in the Wild (1995; Cambridge, MA: MIT Press). Hutchins pokazuje, że w przypadku grup społecznych wykorzystujących narzędzia oraz infrastruktury materialne mamy do czynienia z zupełnie nową jakością procesów poznawczych, wiodących do ciekawych rezultatów. Indywidualne jednostki pozbawione wsparcia technologicznego nie mogłyby takich rezultatów osiągnąć [przyp. tłum.].
} 
do zrozumienia społecznego podłoża procesu projektowania i działalności wytwórczych (Blau, 1984), a także badania skutków projektowania architektonicznego, społecznie konstruowanych w negocjacjach między architektami a szeregiem innych uczestników (Cuff, 1991). Zakładając, że „osiągnięcia antropologii nauki i technologii można przenosic’” na studia nad architekturą (Callon, 1996), niniejszy artykuł wykorzystuje Teorię Aktora-Sieci jako metodę rozwiniętą pierwotnie w kręgu STS do badania nauki, technologii i praktyk inżynierów, a następnie wykorzystywaną poza swoją pierwotną dziedziną odniesienia do analizy tak różnych obszarów, jak badania problemu uzależnienia od narkotyków czy muzyków-amatorów (Gomart, Hennion, 1999). Wykorzystanie perspektywy STS nie będzie oznaczało uznania budynków za artefakty techniczne czy naukowe. Chodzi raczej o uruchomienie narzędzi ANT, uparcie tworzonych w celu objaśnienia oraz zrozumienia (a nie odkładania na bok) obiektów architektonicznych, związanych z nimi instytucji oraz różnych kultur (Latour 2005). Celem niniejszego artykułu jest ukazanie społecznej i poznawczej złożoności „renowacji w działaniu”. Będziemy tu podążać za trudnościami, nieprzywidzianymi zwrotami, niespodziankami i modyfikacjami procesu renowacji oraz przekształcania zabytkowego budynku Wiednia - Alte Aula. Przekonamy się, że budynek historyczny, zamiast biernie poddawać się zabiegom renowacyjnym, może odgrywać ważną rolę mediacyjna - ustalając ścieżki, stwarzając okazje, przekierowując i w znacznym stopniu ułatwiając proces renowacji. Dzięki światłu rzuconemu przez ANT na proces renowacji zyskamy nową definicję budynku i sprawczości.

\section{Jak badać budynki jako nieustabilizowane byty}

W 2000 roku wiedeński architekt Rudolf Prohazka otrzymał zlecenie renowacji siedemnastowiecznego budynku należącego do Starego Uniwersytetu w Wiedniu, znanego jako Alte Aula. Budynek ten znajduje się w dzielnicy uniwersyteckiej, wybudowanej w 1623 roku, kiedy to cesarz Ferdynand IV powierzył prowadzenie wydziału teologicznego i filozoficznego Zakonowi Jezuitów. Budynek położony przy Backerstrasse 20 był wtedy obiektem akademickim, w którym odbywały się również uroczystości uniwersyteckie i przedstawienia teatralne. Przez następne stulecia pełnił on rozmaite funkcje.

Latem 2004 roku, krótko po tym, gdy zaczęłam pracować dla Austriackiej Akademii Nauk, która zarządza obecnie Alte Aula, postanowiłam prześledzić przebieg renowacji tego obiektu, towarzysząc odpowiedzialnemu za ten projekt architektowi w jego wysiłkach przekształcania i odnawiania jednego z najstarszych budynków w centrum Wiednia. Miał on wkrótce stać się siedzibą muzeum nauki nowego typu - Galerii Badań Naukowych. Moim celem było zrozumienie złożoności procesu renowacji przez wzięcie pod uwagę wysiłków różnych wciągniętych w ten proces aktorów, ludzkich i pozaludzkich: Federalnego Urzędu ds. Ochrony Zabytków (Bundesdenkmalamt), Federalnego Ministerstwa Gospodarki i Pracy (Bundesministerium fur Wirtschaft und Arbait), Bundes Immobilien 
Gesellschaft $(B I G)^{5}$, specjalnego departamentu Ministerstwa Gospodarki i Pracy odpowiedzialnego za zarządzanie budynkami publicznymi w Wiedniu (Burghauptmannschaft) ${ }^{6}$, firmy budowlanej Swietelsky, architektów, konserwatorów, klientów, fasady budynku, kamienia użytego do wyłożenia podłogi, siatki kolumn, fresku i warstw malarskich. Wraz z dwójką moich współpracowników w toku całego tego przedsięwzięcia, aż do ostatecznego ukończenia renowacji budynku w 2006 roku, podążaliśmy za wskazanymi wyżej aktorami wszędzie tam, gdzie planowano, dyskutowano i negocjowano. Byliśmy świadkami zaangażowania aktorów w długotrwałą operację przekształcania budynku i tworzenia jego kolejnych redefinicji. Obserwowaliśmy to, jak wyrażali oni swoje obawy, zmieniali kryteria, komunikowali wzajemne oczekiwania i angażowali się w negocjacje. Podążając za tymi aktorami, mogłam potraktować renowację nie jako serię „heroicznych” bitew stoczonych przez architekta z niezmienną „,substancją historyczną”, lecz raczej jako przedsięwzięcie zbiorowe - niepewne, trudne i kontrowersyjne - mające na celu przekształcenie, zredefiniowanie, przeformułowanie i ustanowienie na nowo budynku Alte Aula.

Kiedy mówię o „substancji historycznej”, odnoszę się do większości definicji budynku historycznego, których używa się w badaniach nad ochroną i konserwacją zabytków. Uwypuklając wyjątkowe znaczenie budynków i uzasadniając potrzebę ich konserwacji, teorie konserwacji przekonują, że powinniśmy zachować dawne budynki ze względu na ich architektoniczną wartość, ,patynę wieków” (Ruskin, 1989), substancję budowlaną (Bausubstanz), znaczenie symboliczne i „wartość historyczną” (Alterswert). Zakłada się tutaj, że „Ślady upływu czasu” i oznaki przedwczesnego starzenia (Dehio, Riegl, 1988) to najważniejsze cechy zabytków, gwarantujące ich „oryginalność” czy też „,autentyczność”. Integralność strukturalna i stałość przestrzenna są postrzegane jako cechy wyróżniające budynków (w porównaniu z dziełami sztuki czy wartościowymi przedmiotami), stanowiąc warunki sine qua non ich doniosłości oraz znaczenia. Z drugiej strony, budynki są postrzegane jako ważne „dowody”, świadectwa historii społecznej oraz „pomniki” pamięci zbiorowej, przekazywanej przez stulecia. Są to kolejne powody, dla których warto chronić zabytkowe budowle. Konserwatorzy często zmagają się z dylematem, czy „utrzymać pierwotną materię budynku”, to znaczy architektoniczną jakość zaprojektowaną w punkcie wyjścia przez architektów i budowniczych, czy raczej ,zachować czytelność zapisu historii”, zapewniając widoczność i rozpoznawalność wszystkich interwencji konserwatorskich i śladów historii widocznych na powierzchni budynku. Koncentrując się na identyfikowaniu wartości symbolicznej, pierwotnej istoty oraz warstw historycznych danych zabytków, teorie konserwacji interpretują budynki jedynie w oparciu o to, czym one są i co znaczą. Nie bierze się tutaj pod uwagę ich możliwości działania, zmieniania oraz manifestowania

\footnotetext{
${ }^{5}$ Bundes Immobilien Gesellschaft to największy właściciel nieruchomości w Republice Austrii.

${ }^{6}$ Departament ten jest właścicielem budynku, podlegając Ministerstwu Gospodarki i Pracy. Reprezentują go inżynierowie mający duże doświadczenie w zarządzaniu budynkami oraz w prowadzeniu wielkich projektów renowacyjnych. W tekście posługuję się terminem niemieckim.
} 
sprawczości podczas interweniowania w nie w procesach restauracji oraz renowacji. Chodzi o to, że w badaniach nad konserwacją i ochroną zabytków budynki przez długi czas po prostu nie były uznawane za aktorów.

Nie miały one szansy odegrać jakiekolwiek roli w omawianych teoriach również dlatego, że mieliśmy do czynienia z dominacją takich, a nie innych definicji aktorów i sprawczości. Działanie jest bowiem zazwyczaj interpretowane jako coś, co ludzie (konserwatorzy, renowatorzy, opiekunowie dziedzictwa) ,intencjonalnie” i „w rozumiejący sposób” robią z bierną tkanką budynku. Działania te nazywane są ,interwencjami” (rozumianymi jako świadome angażowanie się w próbę zmiany czegoś w pewnych sytuacjach). $Z$ tego powodu trudno jest dostrzec, że budynek, fresk, łuk czy siatka kolumnady mogłyby działać. Interwencja ma jednak również inne znaczenie, odnoszące się do interakcji z istniejącym budynkiem. Takie rozumienie przyznaje pewien stopień sprawczości obiektowi, w którego proces przekształcania interweniują architekci, konserwatorzy i budowniczowie. Wynika z tego także to, że sprawczy obiekt może okazać się nieposłuszny.

Studium dotyczące Alte Aula podważa tradycyjne, substancjalne rozumienie budynków jako stałych i niezmiennych bytów. Nasz sposób ujmowania ich sprawczości różni się od interpretacji przyjmowanej w badaniach konstruktywistycznych, w której rozważa się ją jako coś, co tworzy tożsamość i strukturyzuje stosunki społeczne, a także „wraca do ludzi, gdy budynek zostaje opowiedziany i zreinterpretowany - dyskursywnie ustanowiony na nowo" (Gieryn, 2002). Alte Aula jawi się w naszym badaniu jako budowla-w-procesiestawania-się, a nie jakaś trwała i opierająca się czasowi forma tożsamości. Poddana licznym przekształceniom w ciągu czterystu lat swojego istnienia, Alte Aula ciągle wyzwala zmiany i prowokuje różnice zdań. Stawiając wyzwania współuczestnikom procesu swojej renowacji, budynek na nich oddziałuje: skutecznie redefiniuje relacje między nimi i zmienia to, jak rozumieją oni świat architektury. Rozszyfrowując złożoność procesu renowacji Alte Aula, będziemy kierować się następującymi pytaniami: czy budynki historyczne wiernie przekazują znaczenia społeczne i wartość historyczną? Na jakich zasadach dają się one poznać i przekształcić? Odpowiadając na te pytania, podążam za nagłymi zmianami niestabilnego-bytu - budynku-w-renowacji. Śledzę praktyki architektów, konserwatorów, wykonawców, władz miejskich i klientów, nie zaś ich ideologie czy teorie. Równocześnie, ukazuję sprawczość zabytku - jego fasady, fresku i materiałów. Wyłania się on jako pełnowartościowy aktor, a nie jakiś drugorzędny nośnik symbolicznego znaczenia czy przedmiot interwencji. Pozwala mi to opisać w duchu ANT, co każdego dnia robia aktorzy ludzcy i pozaludzcy, zarówno indywidualnie, jak i w większych grupach, pomimo ich interesów i teorii. Nieustannie kładę zatem nacisk na pragmatyczny, a nie dyskursywny wymiar działań, zgodnie z rozróżnieniem ,,architektury w procesie tworzenia” i ,architektury wykonanej"7.

\footnotetext{
${ }^{7}$ Nawiązuję do dobrze znanego rozróżnienia na „naukę w działaniu” i „,chłodną naukę” opracowanego przez Latoura (1987).
} 
Otrzymujemy w efekcie ujęcie procesu renowacji w perspektywie ANT (McLean, Hassard 2004) we wskazanym niżej sensie. 1) Omawiane podejście nie wykracza poza okres prowadzonych przeze mnie obserwacji i obejmuje wszystkich uczestników procesu (indywidualnych i zbiorowych, ludzkich i pozaludzkich itd.), którzy dołączyli w tym czasie. Aktorzy ci zostali wybrani na podstawie ilości śladów, jakie odcisnęli na procesie renowacji oraz sposobów, w jakie wzmocnili swoją obecność: uczestniczyli oni w naradach, a ich nazwy pojawiały się w sprawozdaniach oraz programach wielu instytucji i stowarzyszeń, jak również w wywiadach udzielanych przez architektów i opiekunów dziedzictwa; zapelniali oni plac budowy, wizualizacje architektów i wykonawców, a także archiwalia historii budynku i dokumenty klienta. Właśnie dzięki temu zostali oni uznani za „liczących się” aktorów, którzy powinni zostać uwzględnieni w opisie procesu renowacji. 2) Dane zebrane podczas obserwacji są heterogeniczne, ponieważ konserwatorów i historyczne warstwy budynku, architektów i freski traktowano tutaj symetrycznie. Osiągnięto to również przez rozpoznawanie i branie pod uwagę sytuacji, w których czynniki pozaludzkie wchodziły w ,dialog” z ludźmi. Nie było tak, że podążano jedynie za działaniami i zapisami czynności tych, którym zwykle powierza się przemawianie w swoim własnym imieniu. 3) Omawiane podejście nie sprowadza się do zwykłego opisu etnograficznego, ale rozmieszcza aktorów jako elementy w sieci, w krytyczny sposób ujawniając to, co kryje się za obiektami architektury - społeczne znaczenia, czynniki czy siły w działaniu. Rozmieszczanie oznacza skrupulatne branie pod uwagę performatywnych działań całych zbiorowości złożonych z ludzi i czynników pozaludzkich, w miejsce bądź to przypisywania działania wyłącznie konkretnym uczestnikom procesu renowacji (architektowi lub finansującemu ministerstwu), bądź to wyjaśniania renowacji trwałością historycznych struktur czy systemów zabudowy. Stosując ANT jako „bardzo prostą metodę uczenia się od aktorów, bez definiowania a priori ich możliwości działania w świecie" (Latour, 1999), próbuję przezwyciężyć jednostronną interpretację procesu renowacji budynku, która za mocno koncentruje się na podmiotach ludzkich, pozostawiającej niewiele miejsca czynnikom pozaludzkim. W zaprezentowanym tu zastosowaniu ANT, tzn. w opisie procesu podążania za powolnymi przekształceniami budynków jako nie-stabilnych bytów - budynków-w-procesie-stawania-się, uwzględniając przy tym sytuacje ,zaskoczenia” interpretowane jako „wyłomy” w rutynie omawianych procesów, pokazuję, że podczas renowacji budynków, ich naprawy, przeprojektowywania i adaptacji, czynniki społeczne oraz techniczne wspólnie się przekształcają, dlatego ujmuje się je w tej samej perspektywie analitycznej.

Reprezentując Akademię Nauk jako klienta, musiałam brać udział w wielu ważnych dla przebiegu renowacji spotkaniach - w Ministerstwie Gospodarki i Pracy, z firmą budowlaną (8 spotkań, tzw. Bauherrinformation), w firmie budowlanej, a także na samej budowie (23 spotkania). Podczas tych spotkań musiałam artykułować obawy i oczekiwania Akademii Nauk jako przyszłego użytkownika zrewitalizowanego budynku. Obserwując wszystko z tej perspektywy (niecodziennej dla antropologa), będąc równocześnie aktywną uczestniczką tych spotkań, byłam w stanie zrozumieć i wziąć pod uwagę różne aspekty procesu renowacji w sposób niedostępny dla innych uczestników. Podążałam za aktorami, gdy dys- 
kutowali oni plany architektoniczne, modyfikacje budżetu i założenia klientów, gdy zbierali się w biurze, żeby dorysować nowe linie na rysunkach konstrukcyjnych, a także wtedy, gdy spotykali się na placu budowy. Artykuł opiera się dodatkowo na wykorzystaniu wielu innych źródeł: wywiadów z architektem (12 wywiadów), przedstawicielami firmy budowlanej (5 wywiadów), przedstawicielami Federalnego Biura Ochrony Zabytków (3 wywiady), a także na analizie treści archiwaliów Uniwersytetu Jezuickiego i Teatru Jezuickieg ${ }^{8}$, dokumentów Austriackiej Izby Architektów i Inżynierów (Bundeskammer der Architekten und Ingenieurkonsultenten) dotyczących regulacji i ochrony zabytków, dokumentacji konkursu i procesu planowania, jak również na dokumentacji fotograficznej ${ }^{9}$.

Najpierw prześledzę dynamikę procesu renowacji, następnie skupię się na określonych sposobach działania zabytku poddanego renowacji, biorąc pod uwagę to, w jaki sposób działanie jest podzielane i aktywnie dystrybuowane między ulegającymi przekształceniom aktorami a budynkiem, który owym przekształceniom stawia opór.

\section{Dynamika procesu renowacji budynku}

Niektórzy autorzy bronili przekonania, że ze swej natury proces projektowania jest przewidywalny i intencjonalny (Boudon, 1990). Kierują nim jasne założenia i cele (Lebahar, 1987). Podkreślali oni istnienie pozwalających się przewidzieć ograniczeń (spodziewanych, starannie wycenianych oraz szacowanych), uznając umiejętność ich zrozumienia za jedną z podstawowych, twardych kompetencji eksperta-architekta, mimo wzrostu zainteresowania znaczeniem działań negocjacyjnych (Raynaud, 2001). Jednak, choć proces renowacji Alte Aula rozpoczął się od konkretnego projektu architekta Rudolfa Prohazki, który po wygraniu międzynarodowego konkursu w 2000 roku jasno określił cele renowacji i sposoby jej realizacji, przedsięwzięcie to w latach 2004-2006 okazało się procesem nieprzewidywalnym i nieciągłym, znoszonym w różne strony i ukierunkowywanym przez „niespodzianki”, ,zerwania” i ,zmiany dotyczące szczegółów”.

Architekt wskazuje na niemożność precyzyjnego zaplanowania poszczególnych etapów renowacji oraz potrzebę nieustannego dokonywania korekt i dostosowywania wyników pierwotnie zaplanowanych działań:

Nigdy w swojej karierze nie realizowałem projektu, który nie miałby jakichś ograniczeń. Istnieje całe mnóstwo ustalonych wcześniej obostrzeń, takich jak normy czy prawa, które obowiązują bez względu na wszystko. Przykładowo, łatwo jest zaplanować użycie niebieskich materiałów, jednak ich późniejsze korygowanie i dopasowywanie spowoduje pojawienie się znacznych kosztów dodatkowych. (wywiad z architektem R. Prohazką)

\footnotetext{
${ }^{8}$ Na potrzeby bieżącego badania przeprowadziłam kwerendy w następujących archiwach: Staatsarchiv (Archiwum Państwowe) - Allgemeines Verwaltungsarchiv (Powszechne Archiwum Administracji) oraz Haus-, Hofund Staatsarchiv (Archiwum Cesarskie); Wiener Stadt- und Landesarchiv (Archiwum Miasta Wiednia); Universitätsarchiv (Archiwum Uniwersyteckie).

${ }^{9}$ Do udokumentowania procesu renowacji został wynajęty fotograf. W rezultacie otrzymaliśmy ponad 400 fotografii różnych stadiów renowacji.
} 
W wyniku szeregu problemów związanych z renowacją, pośród uczestników omawianego procesu rozgorzały spory i wystąpiły różnice zdań, co sprawiło, że pierwotny plan architekta nie mógł zostać realizowany z zakładaną precyzją. Nie mógł on przynieść dokładnie takich rezultatów, jakie przewidywał. Kwestie problematyczne są zazwyczaj dyskutowane podczas spotkań w firmie budowlanej, na których architekci, wykonawcy, przedstawiciele Burghauptmannschaft i klienci omawiają sprawy techniczne oraz finansowe. Dyskusje dotyczące kwestii finansowych, w porównaniu do problemów związanych ze sprawami technicznymi i dotyczącymi wykonania, są bardziej złożone i czasochłonne. Firma budowlana Swietelsky odpowiadała zarówno za sprawy techniczne, jak i finansowe, dostarczając dokładnych wyliczeń i rozwiązań technicznych. Każde odstępstwo od pierwotnego projektu musi być negocjowane i uzasadnione. W trakcie dyskutowania dodatkowych kosztów czy kwestii technicznych związanych z wykonaniem, aktorzy nieustannie odnoszą się do specyfikacji zawartych w propozycji ofertowej przetargu ${ }^{10}$.

Jedno z najczęściej dyskutowanych zagadnień dotyczyło tego, jak zaadaptować i przekształcić salę $\mathrm{z}$ freskiem w nowoczesną salę konferencyjną, która mogłaby pomieścić około 150 osób. Pomieszczenie to musiało zostać poddane gruntownemu remontowi i wyposażone w nowoczesne udogodnienia i sprzęty, przy jednoczesnym uwzględnieniu, że znajduje się w nim jeden z największych fresków w Wiedniu, chroniony przez przepisy Organizacji ds. Ochrony Budynków Historycznych i Zabytków. Burghauptmannschaft oraz Ministerstwo Gospodarki i Pracy wielokrotnie interweniowały w negocjacjach z architektem. W wywiadzie z 2004 roku były przewodniczący Akademii Nauk, Werner Welzig, który walczył o to, by budynek Alte Aula stał się budynkiem Akademii, opowiadał o trudnych zmaganiach z innymi instytucjami, takimi jak Uniwersytet Muzyczny czy Opera Wiedeńska. Instytucje te także chciały pozyskać Alte Aula dla swoich potrzeb: „Szybko zrozumieli, że salę teatralną na drugim piętrze niełatwo jest wykorzystać, w szczególności ze względów akustycznych”. Welzig musiał zaangażować się w trudne negocjacje z kilkoma urzędnikami federalnymi wyższego szczebla, żeby przekonać ich do przeniesienia Centralnego Urzędu Statystycznego (Statistische Zentralamt) z Alte Aula, by pozyskać „najstarszy służący nauce budynek w Austrii” na potrzeby Akademii Nauk. Wypowiadając się na temat trudności związanych z przekonaniem urzędników do tego, że możliwe jest zaadaptowanie logiki przestrzennej i rytmu funkcjonowania siedemnastowiecznego budynku do nowoczesnego wyposażenia i technologii, architekt stwierdził: „Osiągnięcie porozumienia zabrało nam bez mała rok”.

Uczestnicy procesu renowacji dyskutowali ze sobą zawzięcie na temat użycia odpowiedniego materiału na posadzki, także i w tym wypadku powołując się na ewentualną niezgodność z wyjściowymi planami architekta. Ponieważ należało ściśle przestrzegać ograniczeń budżetowych, architekt nie chciał zastosować kamienia naturalnego, sugerując w zamian

\footnotetext{
${ }^{10}$ Traska (2006) pokazuje, że budynki zabytkowe są niesatysfakcjonująco przedstawiane w ofertach w konkursach przetargowych. Pokazuje on, jak traktować ekspertyzy konserwatorów zapewniając wyczerpującą reprezentację tego rodzaju budynków w procesie przygotowywania dokumentacji przetargowej.
} 
użycie magnezytu (pewnego rodzaju sztucznego kamienia) - „przyjaźniejszego i ładniejszego materiału". Wielokrotnie nalegał on na to, by podłoga była taka, jak było to pierwotnie zaplanowane. „To lepiej przystaje do naszych możliwości” argumentował raz po raz Prohazka na spotkaniach planistycznych i podczas rozmów osobistych, próbując jak najlepiej dopasować się do ograniczeń budżetowych. Doszło na tym tle do licznych dyskusji z udziałem klienta, wykonawców i przedstawicieli Federalnego Biura Ochrony Zabytków oraz Ministerstwa Gospodarki i Pracy. Aktorzy ci intensywnie omawiali właściwości wspomnianych materiałów, ich zalety estetyczne, trwałość, sposób montażu i ułożenia. Przy wielu okazjach porównywali oni próbki kamienia i magnezytu, a także podliczali i przeliczali budżet w oparciu o obydwie opcje. Liczne spotkania wykonawcy (Bauherreninformation) w Ministerstwie Gospodarki i Pracy poświęcono temu samemu dylematowi: naturalny kamień czy magnezyt? Wersji z kamieniem bronili głównie przedstawiciele ministerstw finansujących projekt, podkreślając znaczenie trwałości posadzki, która w dłuższej perspektywie będzie wymagała mniejszej ilości interwencji, nawet jeżeli należałoby to osiągnąć za cenę znacznego przekroczenia budżetu. Architekt wraz z niektórymi przedstawicielami klienta bronili magnezytu jako rozwiązania tańszego, które uelastyczni budżet i pozwoli zaoszczędzić część środków na ewentualne ulepszenie całej infrastruktury budynku. Owa druga grupa aktorów pozostawała obojętna wobec argumentu dotyczącego trwałości: zakładali oni, że jako budynek wystawienniczy, Alte Aula powinna być przygotowana na mogące zajść wraz z upływem czasu liczne zmiany i dostosowania. Ostatecznie kamień naturalny pokonał magnezyt, a trwałość zatriumfowała nad elastycznością.

Jak z tego wynika, uczestnicy omawianego procesu angażowali się w negocjacje, które modyfikowały przebieg renowacji przeformułowując jej cele, przekształcając naturę biorących w niej udział aktorów, a także modyfikując kompromisy osiągane przez architektów, klientów, planistów, obrońców dziedzictwa i ministerstwa. Pozwala nam to stwierdzić, że renowacja nie rozpoczęła się od rzetelnego i przewidywalnego badania historycznego, stanowiącego inspirację dla błyskotliwych rozwiązań, które wcielono w plany projektu realizowanego następnie zgodnie $\mathrm{z}$ oczekiwaniami wszystkich uczestników. Zamiast tego okazało się, że modyfikowany budynek to nieoczekiwany i nieprawdopodobny rezultat niepewnych procesów opartych na nieporozumieniach, śmiałych, a niekiedy arbitralnych, eksperymentów oraz sprawdzianów, w których początkowe decyzje architekta ulegały zmianie ze względu na nieznane czy lekceważone dotąd czynniki. Oto jak renowacja może czasem prowadzić do przypadkowych rezultatów. 


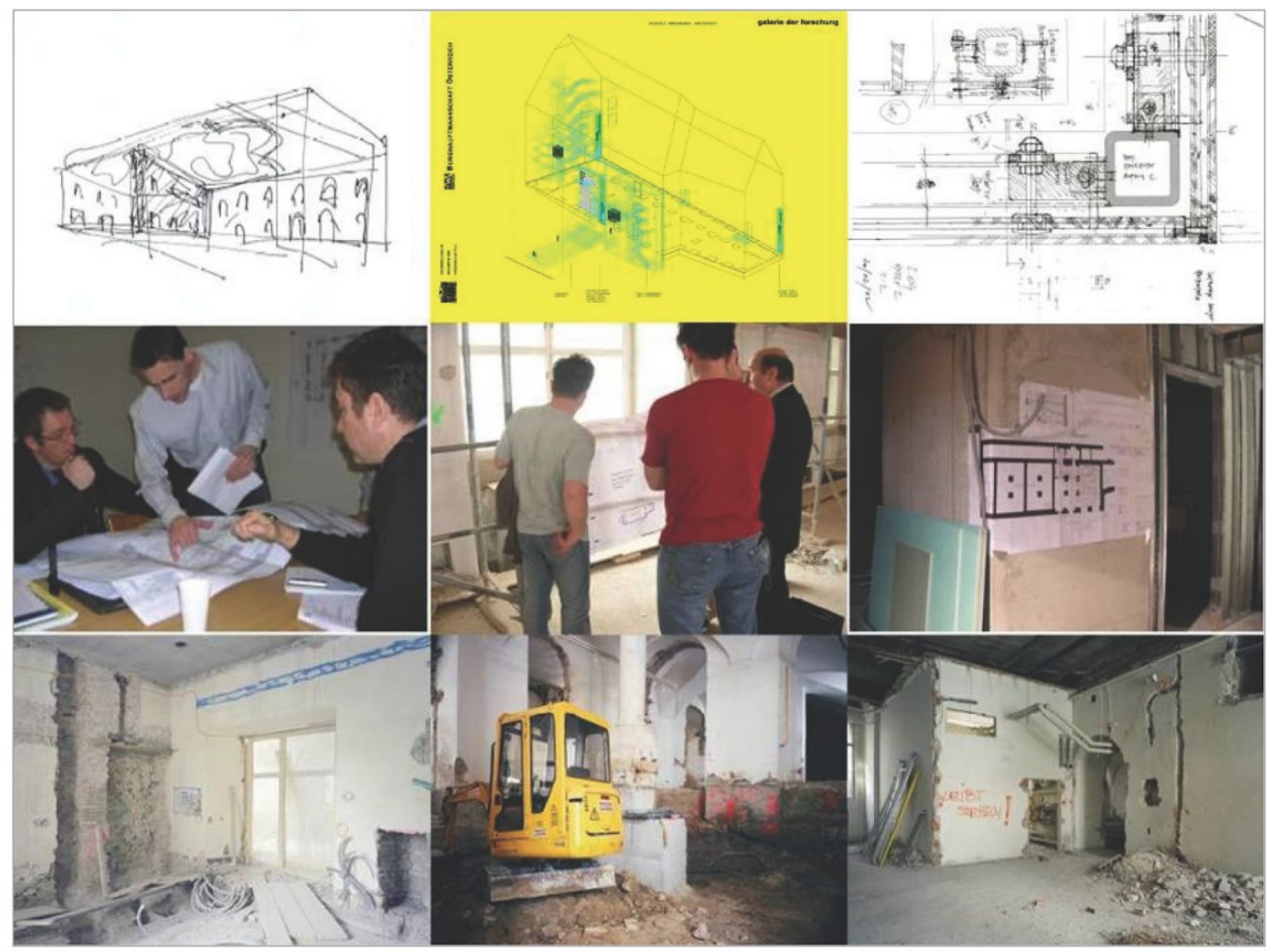

Ilustracja 1. Innowacja w dzialaniu. (Zdjęcia i kolaż autorki)

Ostatnie prace z zakresu socjologii translacji pokazały, że koncepcje, projekty i sam proces tworzenia są negocjowane - dlatego negocjacja i kompromis stały się kluczowymi pojęciami socjologii nauki i technologii (Latour, Callon, 1982). Negocjowanie jest uważane w tej tradycji za aktywność społeczną, rozpoczynającą się od zaistnienia konfliktu interesów między co najmniej dwoma aktorami czy tendencjami i zmierzającą do akceptowalnego przez wszystkich porozumienia, przybierającego często formę kompromisu. Proces renowacji również można badać, śledząc liczne negocjacje oraz kompromisy zawierane $\mathrm{w}$ jego trakcie, podobnie jak ma to miejsce w przypadku negocjacji zbiorowych stosowanych przez firmy architektoniczne przebadane przez Cuffa (1991). Kiedy znajduje się pośrednie rozwiązanie, np. w sporze o kamień czy magnezyt, znaczenie podłogi, właściwości materiału, trwałość budynku i częstotliwość zabiegów renowacyjnych zmieniają się wraz z nabywaną przez nas wiedzą o właściwościach tych dwóch materiałów, ich cenie, estetyce, a także ich znaczeniu dla zaplanowanych w projekcie własności remontowanego budynku i więzi społecznych, które z nich wynikają. O ile podczas kontrowersji 
wokół sali z freskiem Federalne Biuro Ochrony Zabytków nałożyło specjalne ograniczenia na koncepcję architektoniczną, to w sporze „magnezyt czy kamień naturalny” byliśmy świadkami dynamiki negocjacji dotyczących projektu, podczas których architekt włączał nowe informacje do początkowego planu architektonicznego, wielokrotnie go dostrajając, tak samo jak inni aktorzy dostrajali swój budżet i oczekiwania. Magnezyt i kamień również brały aktywny udział w dyskusjach w ministerstwie i na placu budowy, nakładając określone, materialne wymogi na proces renowacji.

\section{Sposoby dzialania budynku-w-renowacji}

Przebieg renowacji charakteryzują nieprzewidywalne zwroty akcji również dlatego, że budynek poddany renowacji nie jest w pełni podległy: ujawnia swoje nieposłuszeństwo, opierając się często zaplanowanym interwencjom. Klienci, budowniczowie i architekci nie potrafią $w$ pelni przewidzieć i kontrolować przyszłych zmian.

Pierwsze spotkanie Rudolfa Prohazki z budynkiem Alte Aula nastąpiło w 2000 roku, kiedy został on zaproszony przez Akademię Nauk do wzięcia udziału w konkursie na projekt jego renowacji. Jako wiedeński architekt Prohazka był początkowo zaintrygowany „,niecodziennym umiejscowieniem urbanistycznym tego budynku", tamującym jedną stronę uliczki Riemergasse, która w średniowieczu biegła w poprzek budynku, prowadząc do dzielnicy Jezuitów. Istniało jedynie wąskie przejście w kierunku Wollzeile (małej uliczki handlowej w centrum miasta na tyłach katedry św. Stefana), a sam budynek skierowany był ku Seipelplatz (gdzie znajduje się główny gmach Austriackiej Akademii Nauk) i przylegającej do tego placu Bäckerstrasse. Prohazka przystąpił do konkursu zachwycony wyzwaniem renowacji starego budynku w centrum Wiednia w celu przekształcenia go w siedzibę instytucji naukowej, co oznaczało, że „nowym, nowoczesnym przeznaczeniem” Alte Aula będzie umożliwianie komunikacji naukowej. Trudność polegała na otwarciu budynku na Wollzeile w taki sposób, aby „stawić czoła skierowanemu na budynek naporowi pieszych z ciągnącej się przez 200 metrów Riemergasse" (wywiad z Prohazką). Odnowienie tego budynku stanowiło dla wiedeńskiego architekta przede wszystkim ogromne wyzwanie dokonania interwencji urbanistycznej, równie trudne i wyczerpujące, jak każda inna interwencja w tkankę centrum jednego z najstarszych miast europejskich (Appleyard, 1979).

Mój pierwszy kontakt z budynkiem Alte Aula był wynikiem zaproszenia przez Akademię Nauk do uczestnictwa w konkursie, które otrzymałem wraz z 9 innymi osobami. Jeśli dobrze pamiętam, było to latem 2000 roku. W tym czasie nie mogłem zobaczyć budynku w całości. Kompozycyjne i przestrzenne cechy budynku można było obejrzeć tylko na drugim piętrze i parterze, ponieważ pierwsze piętro było całkowicie przesłonięte przez samowolne przeróbki, wybudowane w sposób niezgodny ze strukturą budynku. Zadanie przebudowy budynku i możliwość tchnięcia weń nowego życia zafascynowały mnie... (wywiad z architektem R. Prohazką)

Architekt odpowiedzialny za budynki Akademii Nauk (architekt Schuh), który również obejrzał Alte Aula na etapie poprzedzającym jakiekolwiek prace renowacyjne, zgodził się co do tego, że należy pozbyć się śladów poprzednich funkcji i interwencji, dzięki czemu 
budynek ukaże swe „zalety przestrzenne”. Obydwaj architekci utożsamiali renowację z „oczyszczeniem” i „uwolnieniem” budynku ze śladów wszystkich jego poprzednich funkcji, jak również ostatnich przebudów i interwencji po to, by przywrócić mu, na ile to możliwe, jego pierwotny układ. Zamiast angażować się w doszukiwanie się intencji „pierwszego planisty”, odróżniając „,pierwotną istotę” (Originalsubstanz) budynku od dodatkowych, nagromadzonych z biegiem lat warstw, architekt musiał znaleźć inne sposoby, dzięki którym stary budynek ujawni sam siebie architektom, planistom i budowniczym. Wykorzystywał on źródła pisane dotyczące historii budynku, m.in. książkę Mühlbergera (1993) uważaną za główny punkt odniesienia na etapie prac badawczych. Przekonywał on jednak ponadto, że:

prawdziwym źródtem informacji byt sam budynek. Znajdowało się w nim tak wiele nieudokumentowanych wcześniej, nieznanych rzeczy, takich jak fragmenty fresków, odkryte nagle różnice, techniki... przez cały czas mieliśmy do czynienia z jakimiś niespodziankami w negatywnym tego słowa znaczeniu: dlaczego tak źle to wybudowali? Po co im były te drewniane części? Wiele rzeczy należałoby poprawić, co byłoby normalne w przypadku nowej zabudowy. Nie powiedziałbym, że jest czymś nietypowym dla tak starego budynku, że jego fundamenty nie są już w tak idealnym stanie, jak w budynkach współczesnych. Gdybyśmy budowali taki budynek dzisiaj, trudno byłoby nam wyobrazić sobie jego trwanie w perspektywie kolejnych 400 lat. Jeśli zostawisz go otwartym i niedokończonym, budynek po prostu zyska na jakości. (wywiad z architektem R. Prohazką)

Zdobywanie wiedzy na temat budynku - coś, od czego zaczyna się każda renowacja lub projekt - sprowadza się raczej do doświadczania tych konkretnych technik, dzięki którym budynek-w-procesie-renowacji pozwala się poznać i zdobyć o nim wiedzę. Stare budynki nie tylko przystosowują się do nowych funkcji, ale również oprowadzają odwiedzających po swych wnętrzach, „funkcjonują jako siedziby różnego rodzaju programów”, a także wywołują dyskusje i spory. Jednocześnie, ani materialność i historia budynku nie determinują w pełni działań wszystkich ,interweniujących” (architektów, wykonawców, obrońców dziedzictwa, konserwatorów), ani nie jest też tak, że budynek w trakcie renowacji stanowi jedynie tło ludzkiego działania. Proces renowacji sytuuje się pomiędzy przyznaniem budynkowi pełnej sprawczości a zupełnym go jej pozbawieniem. Żeby zrozumieć co dzieje się podczas procesu renowacji budynku, musimy najpierw przedstawić wielość sposobów działania budynku: może on pozwalać, zaskakiwać, czynić możliwym, podpowiadać, ułatwiać i wpływać na innych aktorów i możliwe działania.

Sytuacja bycia „zaskoczonym” przez siedemnastowieczny budynek ma istotny wymiar czasowy i poznawczy, to właśnie dzięki temu odróżniamy momenty zaskakujące od niezaskakujących w procesie renowacji. O ile zdarzenie przewidywalne pozwala uczestnikom renowacji kontynuować zaplanowane wcześniej działania, o tyle „niespodzianka” zakłóca je, wymuszając ponowne oszacowanie całego procesu. Aktorzy zatrzymują się na chwilę i odgrywają specyficzny, retrospektywny gest podania w wątpliwość samej struktury budynku: „Dlaczego tak to zbudowano? Dlaczego wykorzystano te drewniane elementy? Dlaczego fundamentów budynku nie zbudowano w taki sposób, w jaki architekci zrobili to dziś?" (refleksji tego typu dokonuje się na podstawie archiwaliów). Następnie 
wracają oni do teraźniejszości, żeby poprawić, odmienić i dostosować budynek dzięki wykorzystaniu dostępnych obecnie technik. Współczesny architekt zanurzony w gąszczu problemów i pułapek toczącego się procesu renowacji zarazem uznaje za trudne zaprojektowanie przyszłości budynku obejmującej okres 400 lat. „Myślenie o stabilności budynku” w takiej perspektywie, tj. uwzględnianie możliwości, że inny architekt dokona rewizji dotychczasowych dokonań, ponownie interweniując i przekształcając go (na co również wpłynie sam budynek), nie jest łatwe. Tak więc „,zaskoczenie” odnosi się do tego, że to ludzie nie są w stanie dokładnie zidentyfikować minionych intencji architektonicznych i przedstawić jasnych planów na przyszłość; w tym miejscu sprawczość budynku pozostaje ciągle $\mathrm{w}$ rękach aktywnych podmiotów. Jest to jeden z rodzajów zaskoczenia, które wywołane jest odkryciem nieznanych cech starego budynku, co wynika z tego, że architekci i wykonawcy nie wzięli pod uwagę nieszczęsnych archiwów.

Niezłym zaskoczeniem było na przykład to: na pierwszym piętrze, między długim, szerokim korytarzem a klatką schodową nr 1, gdzie było dużo przestrzeni, znajdowały się bardzo małe, naprawdę trudne do zauważenia i użytkowania drzwi. Osadzono je jednak w grubej ścianie i wyglądały na wartościowe pod względem historycznym. Podczas prac renowacyjnych zauważyłem, że ta bardzo gruba ściana łączyła inne ściany, co dobudowano dość niedawno, a także że właściwie pasuje ona do wielkiego sklepienia (Bogen), pełniącego historycznie rolę otworu drzwiowego. Było to zatem pozytywne zaskoczenie. Potwierdziło ono, że układ budynku był w tamtym czasie bardzo przejrzysty. (wywiad z architektem R. Prohazką)

Opisywane tu zaskoczenie to efekt rozbieżności między zastaną wiedzą na temat budynku (zdobytą w okresie poprzedzającym jego odnowienie) a wiedzą stopniowo zdobywaną w procesie renowacji. Renowacja jest procesem, w którym architekt stara się zrozumieć budynek w takiej postaci, w jakiej był on wcześniej zaprojektowany (jego strukturę, różne aspekty i warstwy) po to, by móc go stopniowo przeobrażać. Jak się wydaje, przeobrażenie jest możliwe tylko wtedy, gdy nie postępuje ono zgodnie z pierwotnym planem, lecz odnosi się do drobnych różnic, które architekt odkrywa podczas przedsięwzięcia renowacji. Fakt, że grubość ściany wykracza poza to, jak powinna ona wyglądać w zabudowie o wysokiej wartości historycznej oznacza, że ściana jest względnie nowa, architekt może wobec tego otrzymać zgodę Federalnego Biura Ochrony Zabytków na jej zburzenie i całkowite odsłonięcie skrytego za nią sklepienia.

Drugi rodzaj zaskoczenia w procesie renowacji wywołuje sam budynek, zmuszając nas do zupełnie odmiennego rozumienia jego sprawczości.

Główny architekt wyjaśnia, że prace postępują zgodnie z planem i wszystko powinno być ukończone na czas: „Zawsze jednak mogą zajść „nieoczekiwane wydarzenia”, np. odkrycia wszelkiego rodzaju. (spotkanie z architektami Prohazką i Mandlerem oraz przedstawicielami klienta, 3 maja 2005 roku)

Postanowiłam przeanalizować takie „nieoczekiwane” wydarzenie wywołane przez pewne fragmenty fresku, które zostały przypadkiem uwidocznione podczas renowacji bocznych ścian na drugim piętrze. Manifestacja oporu stawianego przez stary budynek Alte Aula miała duży wpływ nie tylko na całą sieć aktorów wciągniętych w tę „niespodziankę”, ale 
również na mnie, z tego względu, że pełniłam zarazem rolę obserwatorki, jak i uczestniczki omawianego procesu. Dlatego w tym miejscu zmodyfikuję nieco ton narracji i w dokładniejszy sposób opiszę pojawienie się tej niespodzianki, a także to, jak zrekonfigurowała ona tradycyjne definicje budynku i jego sprawczości, przekształcając zarazem istniejące sieci. Wszystko zmieniło się dla mnie pewnego majowego poranka 2005 roku, kiedy po otwarciu starych, skrzypiących drzwi wejściowych do budynku weszłam jak zwykle do pustego, remontowanego wnętrza po to, aby wzbudzić w sobie uczucie zachwytu, dzięki któremu mogłabym rozpocząć dzień. Posiadanie klucza do wiekowego jezuickiego budynku było tak ekscytujące i przyprawiające o dreszcze, jak tylko może być posiadanie dostępu do każdego budynku mieszkalnego przepełnionego historią. Zaczęłam swój poranny spacer jak zwykle od szybkiej przechadzki między kolumnami arkad na parterze, by następnie przez dłuższą chwilę kontemplować widok na Riemergasse. Następnie zaczęłam wspinać się nową klatką schodową, znajdującą się obok zaprojektowanej przez Prohazkę szklanej windy, pomijając jak zazwyczaj pierwsze piętro i niecierpliwie zdążając na drugie, do sali z freskiem (Ilustracja 2).

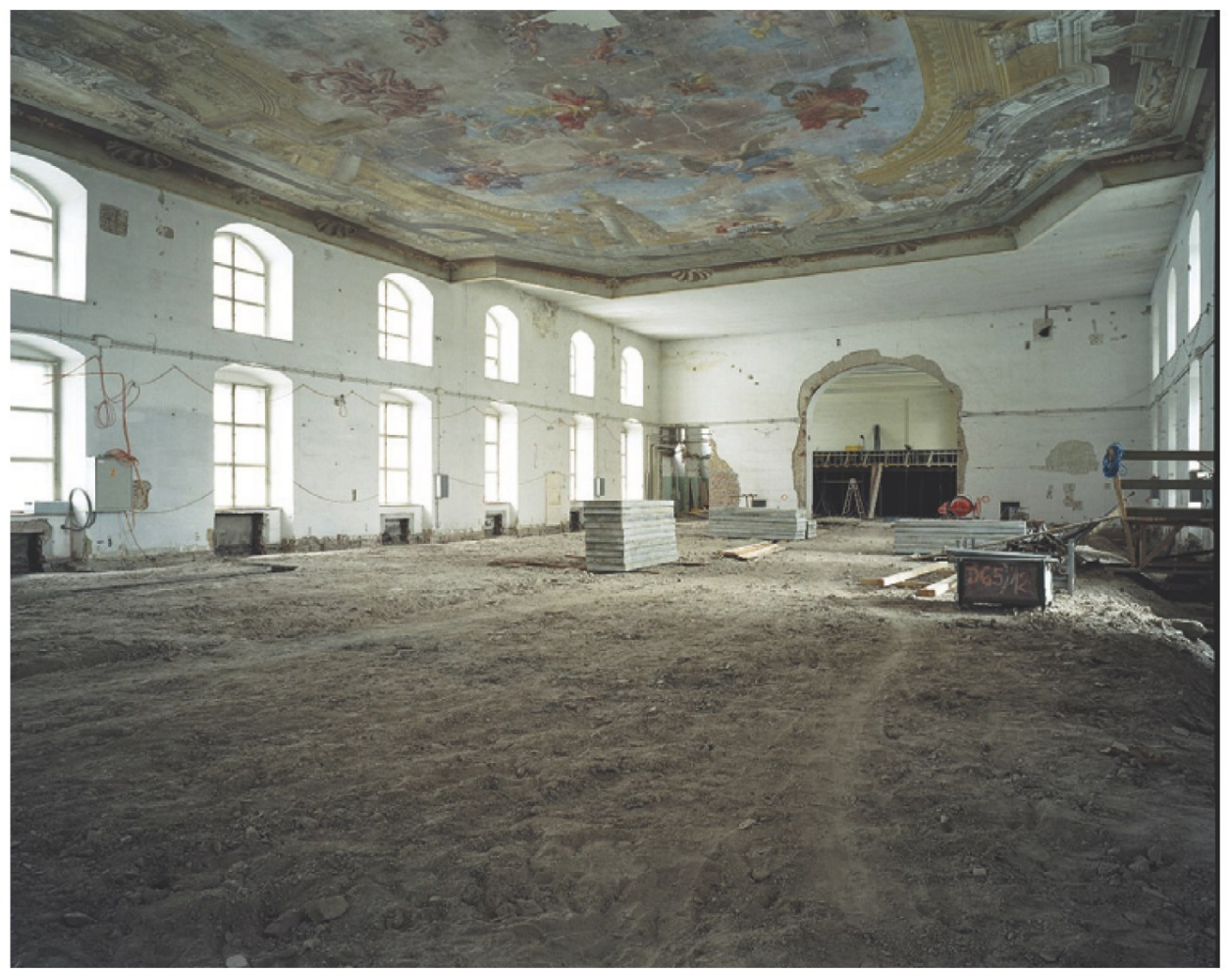

Ilustracja 2. Pokój z freskiem, stary teatr jezuicki. (Zdjęcie autorki) 
Te wspaniałe pomieszczenia spełniały kiedyś wiele funkcji. Po przestudiowaniu zarówno archiwów znajdujących się w dzielnicy uniwersyteckiej w Wiedniu, jak i przeanalizowaniu samych pomieszczeń, często wyobrażałam sobie znajdujące się na piętrze sale, gdzie, według spisu z 1821 roku sporządzonego dla budynku Nowego Uniwersytetu (obecnie Akademii Nauk) [Archiwum Uniwersytetu, CA 1.3.376.], wykładano anatomię i patologię. Według kolejnego, uaktualnionego spisu z 1865 roku na piętrze znajdowała się również sala do wykładów z fizyki, pomieszczenie dla maszyn, obserwatorium oraz gabinet historii naturalnej wraz z przylegającymi pomieszczeniami i laboratorium. Jednak tym, co zawsze mnie fascynowało, w efekcie czego spędzałam całe godziny w tej pustej, liczącej $800 \mathrm{~m}^{2}$ sali (w budynku o powierzchni $3600 \mathrm{~m}^{2}$ ), był sufit $\mathrm{z}$ jednym z największych w Wiedniu fresków, autorstwa Antona Herzoga, a także pozostałości sceny jezuickiego teatru. W czasach jezuitów, w theatrum ${ }^{11}$ odbywały się nie tylko przedstawienia, ale również uroczystości uniwersyteckie, takie jak promocje. Calendarium academicum z 1693 roku zawiera obraz przedstawiający jedno z tych wydarzeń. Znajdujące się na drugim piętrze theatrum, wybudowane około 1654 roku dzięki finansowemu wsparciu cesarza Ferdynanda IV pełniło funkcję audytorium dla uroczystości i prezentacji eksperymentów naukowych. Scena została zbudowana w Ratyzbonie i spławiona Dunajem do Wiednia. Teatr, zaprojektowany jako solemne theatrum, wraz ze wszystkimi swoimi mechanicznymi urządzeniami, dekoracjami, wyposażeniem scenografii, barokowymi technologiami scenicznymi, miał wywierać na widzach piorunujące wrażenie.

Ten majowy dzień był bogaty w niespodzianki: spacerowałam po opustoszałej sali z freskiem, bawiąc się jak zwykle w dziecięcą grę „,znajdź różnicę”. Usiłując dostrzec drobniutkie zmiany poczynione w budynku poprzedniego dnia, mój wzrok zatrzymał się na chwilę na bocznych ścianach sceny dawnego teatru jezuickiego. Dojrzałam tam fragmenty żółtawej farby, regularnie rozprowadzone na różnych warstwach; nie było tam jednak narzędzi, planów architektonicznych ani żadnych ilustracji postawionych poprzedniego dnia. Było dla mnie zaskakujące, że można zostawić ściany w tak okropnym stanie i to na kilka miesięcy przed ukończeniem budynku. Te maleńkie żółtawe warstwy budziły moje obawy, przez co mój poranny zachwyt, który dostarczał mi zazwyczaj energii na cały dzień, stopniowo się ulatniał. [...] Dziwne było to, że nie pozostały tam żadne ślady pracy architektów...

Wychodząc z sali z freskiem architekt Prohazka przywitał mnie szorstkim ale uprzejmym „Gruss Got” i spoglądając na ściany westchnął: „ten budynek zaskakuje nas każdego dnia”. (AY: Dziennik terenowy)

Tamtego majowego poranka 2005 roku fragmenty fresku na bocznych ścianach teatru wywołały u mnie zaskoczenie i zdumienie podobne do tego, które musiał wywierać teatr wraz ze swoją niesamowitą maszynerią i wyposażeniem w czasach, gdy wystawiano jezuickie sztuki. Takie samo wrażenie wywarły one na architekcie, równie zaskoczonym jak ja, że budynek znowu go zaskoczył. Prohazka był bliżej budynku niż ja, znał wszystkie jego

\footnotetext{
${ }^{11} \mathrm{~W}$ porównaniu do nowoczesnego rozumienia teatru, theatrum nie oznacza budynku (czy instytucji), lecz po prostu scenę, która może być bardzo szybko postawiona i rozebrana. Źródła historyczne mówią nam, że theatrum może zostać rozebrane i złożone na nowo w ciągu jednego dnia, ponieważ części łączone były ze sobą bezpośrednio i niezależnie od ścian pomieszczenia.
} 
szczegóły i zakątki, zapoznając się przy różnych okazjach z jego nieposłuszną naturą. Pomimo tego wszystkiego, jego zaskoczenie było większe od mojego - podobnie jak wiedza o budynku, którą dysponował. Poczucie ,zaskoczenia” utrzymywało się miesiącami, wywołując dyskusje pośród wszystkich uczestników renowacji, którzy znosili różne narzędzia i sprzęty do sali z freskiem, aby ją zbadać i sprawić, by przemówiła, angażując w to wszystko coraz więcej czynników pozaludzkich (ilustracja 3).

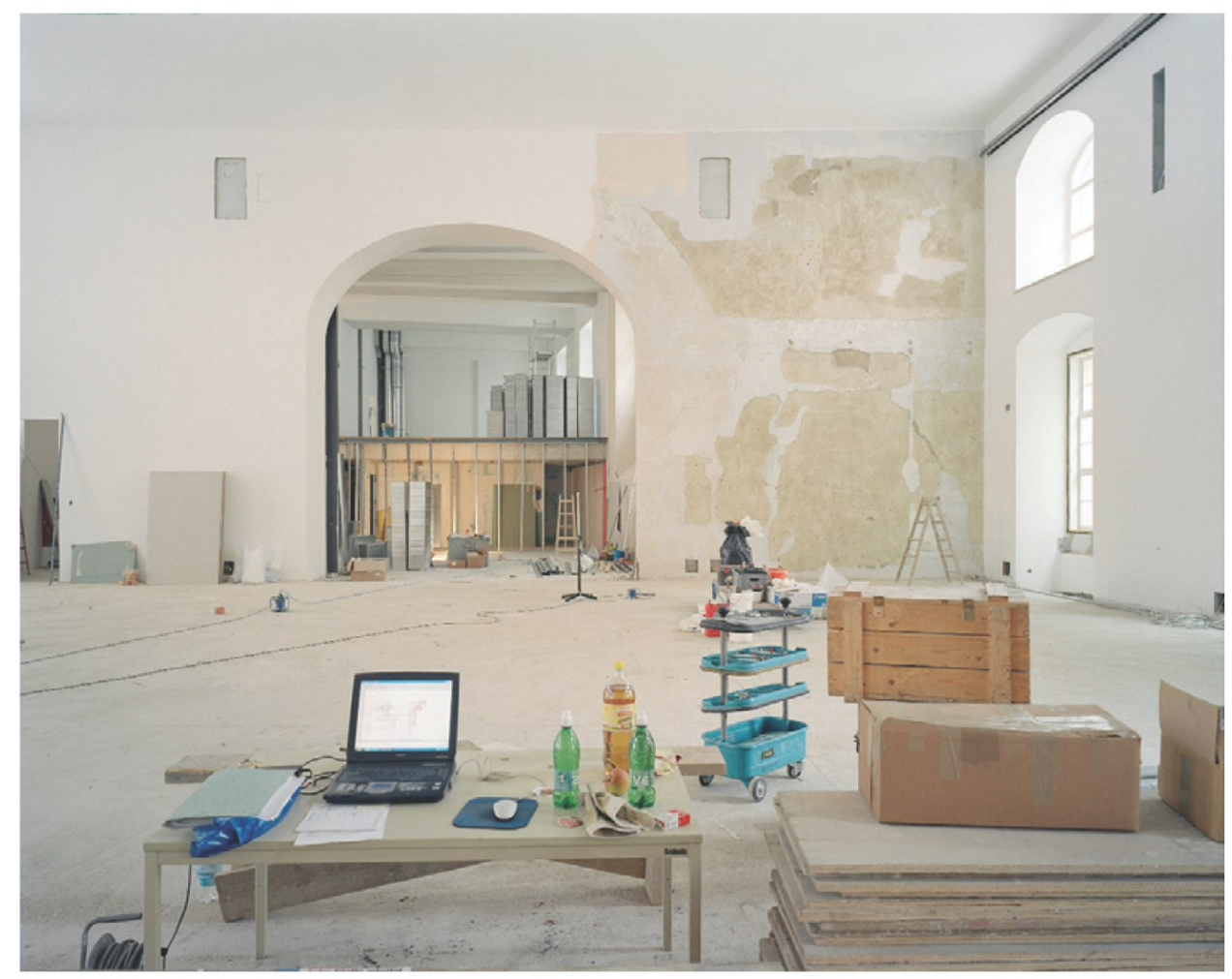

\section{Ilustracja 3. „Niespodzianki” fresku. Nowe malowidło ścienne zostało odkryte podczas prac remontowych (na lewo od okna), co uniemożliwilo dokończenie prac mających na celu renowację ściany w głębi fotografii. (Zdjęcie autorki)}

Kilka dni po tamtej porannej majowej wizycie nowe fragmenty fresku ukazały się również na suficie pierwszego piętra, w miejscu przeznaczonym na wystawy tymczasowe. Ten nowy „sprzeciw” budynku wobec procesu renowacji wciągnął do dyskusji nowych aktorów przedstawicieli Akademii jako klienta, kuratorów, artystów i konserwatorów. Podczas spotkania w siedzibie firmy budowlanej 16 czerwca 2005 roku, opierając się na ekspertyzach konserwatorów, żywo dyskutowaliśmy kwestię materiałów, jakich powinniśmy użyć do odmalowania różnych fragmentów fresku. Rozwiązaniem omawianym na kolejnych spotkaniach było pokrycie fragmentów fresku „Reversillem”, a następnie przemalowanie ich tymi 
samym farbami co sale. Chodziło o to, by pozbyć się śladów nieposłuszeństwa budynku. Klient był pełen obaw dotyczących wyglądu sali wystawowej, oczekując przestrzeni jednolicie neutralnej, która nie będzie konkurować z obiektami na wystawach, a także przewidywalnej, która przestanie zaskakiwać swoich użytkowników „nieposłuszeństwem”.

O ile podczas projektowania aktorzy zmagają się z sytuacjami niedookreślenia, które próbują dookreślić (Schön, 1988), o tyle w procesie renowacji oczekiwania aktorów dotyczą zazwyczaj radzenia sobie ze złożonym, lecz względnie stabilnym obiektem. W pierwszym przypadku, obiekt, którego dotyczy projektowanie, jest dopiero przewidywany, określany i poszukiwany; natomiast w drugim on po prostu tam jest, a uczestnicy renowacji muszą działać zgodnie z nim i $w$ obrębie jego założeń. Wymogi związane z renowacją i dokumentacja procesu konserwacji sugerują, że oczekuje się, iż zabytek pozostanie czarną skrzynką, przewidywalną siecią związanych ze sobą czynników pozaludzkich. Proces renowacji przyznaje uprzywilejowany status systematycznej, stabilnej wiedzy o zabytkowym budynku, nagromadzonej przez stulecia i starannie udokumentowanej w archiwach. $\mathrm{Z}$,zaskoczeniem” mamy do czynienia wtedy, gdy w trakcie interwencji renowacyjnych, obiekt, który miał być spójny i stabilny, zmusza uczestników renowacji do stawienia czoła nowym niepewnościom i wyzwaniom, a także by angażowali się w nowe sieci materiałówkształtów-architektów-warstw-historycznych-i-konserwatorów. „Zaskoczenie” wskazuje również na odmienną epistemologię praktyki renowacji budynku - taką, która wymaga od wszystkich uczestników ponownego zdefiniowania i uelastycznienia swojej wiedzy, kompetencji i kunsztu w sytuacji, gdy rutyna renowacji zostaje ,zerwana” (Garfinkel, 1985). Podczas „refleksji-w-działaniu” (Schön, 1988) uczestnicy renowacji uczą się od budynku, wchodząc we wzajemny, zwrotny dialog z jego materiałami, warstwami i kształtami, który rozgrywa się w sytuacji ,zaskoczenia”, podobnie jak projektanci, którzy uczą się z własnych szkiców, modeli i schematów w procesie projektowania obiektu nieprzekształconego jeszcze w czarną skrzynkę.

Działania związane z projektem renowacji uwidaczniają jednak złożoną sprawczość budynku za każdym razem, gdy jako zamknięta dawno temu we wcześniejszym projekcie czarna skrzynka zostaje on ponownie otwarty, ukazując swe zdolności do działania. W porównaniu do opisanego przez Schöna refleksyjnego procesu komunikacji między architektem a jego szkicami w studiu projektowym, interakcja budynku $\mathrm{z}$ architektami, klientami i konserwatorami jest zdarzeniem, które wykracza swoim działaniem (ang. trans-acts) poza konkretną sytuację ,zaskoczenia”. Ukształtowana w wymianie zdań między architektem, odsłoniętymi fragmentami fresku a mną sytuacja ukształtowała też nasze własne sposoby reagowania i angażowania się w budynek-w-procesie-renowacji, wpływając w dalszej kolejności na innych aktorów w sieci powiązań. Zarówno analiza refleksyjnej praktyki projektantów, jak i badania zapośredniczonych praktyk uczestników renowacji, znacznie różnią się od bardziej tradycyjnego rozumienia projektowania jako przewidywalnej metody planowania (Jones, 1970). Zgodnie $\mathrm{z}$ tą tradycją, nawet studia nad wewnętrzną, sytuacyjną logiką projektowania w działaniu ukazują ten proces jako podzieloną na określone etapy technikę podejmowania decyzji zorientowanych na dany problem, 
która ograniczana jest przez kontekst lub znaczenia społeczne. Badania te podejmują tematykę proceduralnych aspektów myślenia projektowego i normatywności, która kieruje procesem projektowania. Budynek, jego materialność, techniczność i wygląd są tutaj rozumiane raczej jako narzędzie strukturyzujące-problem, niż jako „partner” w heurystycznym przedsięwzięciu badania projektowania (Rowe, 1987).

Omówiona wyżej „niespodzianka” fresku świadczy o tym, że ponownie otwarty zabytek działa jako czynnik sprawczy w projekcie, angażujący więcej materiałów, technik renowacyjnych, klientów, konserwatorów i rozwiązań przestrzennych. „Niespodzianka” fresku działa jak ,eksperyment zaburzający” tok renowacji, pociągając za sobą konieczność przeprowadzenia empirycznego badania, zakłócającego normalne interakcje, dogłębnie naruszającego zasadnicze oczekiwania i dezorientującego uczestników. Nie podważa to jednak założeń leżących u podstaw podzielanego przez uczestników świata. Próbując przywrócić równowagę i unormować działania renowacyjne, ograniczone terminami i napiętym budżetem, uczestnicy procesu renowacji zaangażowali się w próby odtworzenia historii budynku Alte Aula. Narastające spory wokół warstw fresku doprowadziły ich z powrotem do archiwaliów budynku dokumentujących różne pełnione przez niego wcześniej funkcje; począwszy od ufundowania budynku przez jezuitów, przez XIX wiek, gdy służył on nowoczesnym instytucjom, takim jak dziennik Wiener Zeitung (od lat 90. XIX wieku do 1938 roku), Austriacka Drukarnia Państwowa (Österreichische Staatsdruckerei) (która przeniosła się do niego w 1866 roku), a także Centralny Urząd Statystyczny (po II wojnie światowej), aż do obecnej decyzji o renowacji budynku celem przystosowania go do wykorzystania przez Austriacką Akademię Nauk. Podczas historycznej dyskusji wywołanej przez „,buntowniczy” fresk, wszyscy byliśmy przekonani, że najprawdopodobniej żółtawe warstwy były pozostałością po scenografii eksperymentalnego, siedemnastowiecznego teatru. W następnym stuleciu boczne malowidła i rzeźbienia w niszach okiennych zostały ukryte za zasłonami, po to, by uwaga widowni koncentrowała się na przedstawieniach teatralnych. Między 1756 a 1773 rokiem w teatrze na drugim piętrze odbywały się publiczne prezentacje i eksperymenty, natomiast przyległe pomieszczenie od 1715 roku było siedzibą muzeum fizyczno-matematycznego, a także kolekcji eksponatów historii naturalnej zgromadzonej przez jezuitów w trakcie ich podróży (Hamann, Mühlberger, Skacel, 1986). Wnikliwsze przywołanie historii pozwoliło nam doszukać się pewnej estetyki w tych żółtawych i różowawych okrągłych plamach na ścianach.

„Zaskoczenie”, o którym mówił Prohazka tamtego majowego ranka 2005 roku, odnosiło się również nieśmiało do pojęcia sprawczości budynku (a nie do stabilnej wiedzy o nim). Kontrowersje dotyczyły źródła owej sprawczości - tego, jak oddziaływała ona na proces renowacji, w jaki sposób prowokowała do dyskusji i nowych negocjacji między klientami, konserwatorami oraz sponsorami, modyfikując w ten sposób stany rzeczy, z którego stopniowo wyłaniał się budynek jako aktor. Aby ocenić zakres sprawczości budynku, powinniśmy zadać pytanie: czy siedemnastowieczny budynek, jego freski, malowidła i siatka kolumn czynią różnicę w przebiegu działań innych aktorów, czy nie? Jak pokazuje nasze krótkie sprawozdanie z procesu renowacji Alte Aula, odpowiedź brzmi „tak”. Manifestując swą żywotność, fresk odmienił bieg procesu renowacji, przekształcając to, w jaki sposób 
wszyscy uczestnicy procesu rozumieli udaną renowację, zasady organizowania wystaw w siedemnastowiecznych przestrzeniach, a także samą konserwację budynku o bogatej historii. Właśnie ta konkretna, eksperymentalna droga, która pozwoliła wszystkim aktorom odczuć różnicę jest tym, co nazywamy renowacją. Budynek (i jego freski) nie pełnił roli pasywnej powierzchni czy prostego materiału projektowego, ale wyłonił się w tym procesie jako aktor, lub mówiąc dokładniej - aktywny uczestnik przebiegu renowacji budynku.

Również w wywiadach, wielu uczestników przedsięwzięcia określało Alte Aula jako budynek, który reaguje na to, co robią i odpowiada na ich próby delikatnego przekształcania, zmieniania i manipulowania jego tkanką i sprawczością. Choć termin ,interwencji” występuje w zawodowym żargonie konserwatorów, Federalnego Biura Ochrony Zabytków oraz Ministerstwa Gospodarki i Pracy, uwidaczniając się tym samym w stosownych dokumentacjach i protokołach, to jednak sami aktorzy oceniali własne działania raczej jako „odpowiedzi” na rytm i rozkład pomieszczeń budynku. Oznacza to, że możemy doświadczyć drugiego znaczenia terminu ,renowacja”, nie jako intencjonalnego wtargnięcia do pasywnego świata czy obiektu, lecz jako skomplikowanej transakcji opartej na interakcjach między budynkiem, który stopniowo pozwala się poznać, a architektami, klientami i budowniczymi, którzy próbują nauczyć się budynku $w$ procesie jego odnawiania. $\mathrm{W}$ tym drugim rozumieniu renowacja opiera się na wielorakich sieciach aktorów i jest przez nie podtrzymywana.

\section{Opór budynku}

Tak samo jak oporna bakteria czy pierwiastek chemiczny (Stengers, Prygogine, 1988), budynek nie może być całkowicie kontrolowany przez architektów, konserwatorów czy planistów. Nie jest on po prostu ostensywnym obiektem (definiowanym przez wskazanie). Budynek-w-procesie-renowacji jest raczej czynnikiem sprawczym, który opiera się z uporem, utrudnia lub ułatwia konkretne rozwiązania mające na celu spełnianie wymagań programowych renowacji. Podobnie jak koncert, który wykonywany jest i podtrzymywany w istnieniu dzięki złożonym uwarunkowaniom (Hennion, 1993), budynek znika nam z oczu, gdy tylko przestaje być odgrywany (ang. performed). W wielu przypadkach Alte Aula nie miała skrupułów sprzeciwiając się roszczeniom i działaniom architektów oraz budowniczych, blokując działania renowacyjne, utrudniając klientom realizację planów, przeciągając terminy, znikając z pola widzenia, ujawniając nieznane pokłady swej historii, a także rozmaicie reagując na poszczególne materiały i czynniki.

Budynek-w-procesie-renowacji wyłania się jako pełnowartościowy aktor. Oznacza to, że musimy odrzucić tradycyjne definicje budynków jako statycznych scenerii dla aktywności, czy też bytów podporządkowanych prawom i przyczynowości technicznej. $Z$ tezy, że siedemnastowieczny budynek jest aktorem nie wynika oczywiście, iż działa on na podobieństwo niesamowitej maszynerii teatralnej z czasów jezuickich czy też że dosłownie przemówił on do nas tamtego majowego poranka 2005 roku. Działanie oznacza dla budynku, że jest on częścią sieci, w której każdy element „przekazuje”, ,przedłuża” i „wyprzedza" działanie budynku oraz całej zbiorowości. Żaden ze wspomnianych elementów 
nie jest sam w sobie źródłem działania. „Sprzeciw” fresku przedłużał się za sprawą zaskakujących konfiguracji sprawczości wszystkich uczestników renowacji. W rezultacie, jego zdolność do działania jest wynikiem połączeń heterogenicznej sieci (architekt + budynek + warstwy malowideł + konserwatorzy + zwiedzający...). Nie może być ona przypisana do konkretnego ludzkiego aktora w sieci lub do pojedynczego technicznego obiektu, który mógłby determinować kierunek działań.

To, w jaki sposób architekci, budowniczowie i klienci reagowali na „sprzeciwy” ze strony budynku świadczy o ich nieustających wątpliwościach co do tego, czym Alte Aula tak naprawdę jest. Jeśli spodziewali się, że będą mieli do czynienia z posłuszną konstrukcją, której oryginalna tkanka wyglądała na łatwą do uchwycenia, i która mogłaby być przewidywalnym pośrednikiem (ang. intermediary), to tym, co wywołało ich zaskoczenie był fakt, że w zamian mieli oni do czynienia $\mathrm{z}$ wieloma mediacjami, które nieustannie próbowali przekształcić w posłusznych pośredników (ang. intermediary). Budynek-w-procesierenowacji zachowywał się zatem jak wysoce nieprzewidywalny mediator (dzieje się tak zazwyczaj podczas projektowania, gdy czarne skrzynki są otwarte a cele projektu nieustabilizowane (Schön, 1988). Zajmowanie się w ten sposób rozumianym budynkiem, prowadziło uczestników procesu w różnych kierunkach: niezależenie od wcześniejszych badań nad jego historią, często zdarzały się odkrycia dotyczące jego ukrytych warstw; niezależenie od wiedzy na temat jego konstrukcji i materiałów, często zdarzało się im zaskakiwać i być nieposłusznymi. Wynika z tego, że Alte Aula nie była pasywnym tworzywem w rękach konserwatorów i renowatorów ani grzecznym zapośredniczeniem, który przenosi niezmienne znaczenia z XVII wieku do dnia dzisiejszego, odzwierciedlając czy reifikując to, co społeczne. Alte Aula dokonała mediacji (Hennion, 1994), przeksztatcajac działanie na nieoczekiwane sposoby (nie tylko powtarzając je i przenosząc). Zamiast wiernie przenosić przypisane mu znaczenia społeczne przez stulecia, budynek ten zniekształcit je i zmodyfikowat. Zarówno historia, jak i sposoby działania Alte Aula były kwestionowane i redefiniowane w krytycznych momentach ,niespodzianek”.

Podczas renowacji, zaskakujące wydarzenia mające tak duży wpływ na aktorów, nie występowały zbyt często. Dlatego zdecydowałam się zdać relację z rezultatów i konsekwencji tej szczególnej „niespodzianki” wywołanej przez budynek. Oprócz tego, „niespodzianka" opisuje również zasadniczy sposób istnienia w sytuacji swego rodzaju transakcji, którą staramy się zrozumieć, w której budynek manifestuje sam siebie jako przejściowo otwartą czarną skrzynkę. Występuje tu on jako czynnik sprawczy w projekcie, który odpowiada na pytania architektów, konserwatorów i klientów, zmuszając ich do zrozumienia nieoczekiwanych problemów oraz możliwości, sprawiając, by robili więcej, angażując się i ponownie rozważając historię, materialność i formę budynku. Odsłaniając pewne sposoby konstrukcji rzeczywistości, fresk ,zaskoczył” innych uczestników i wymuszał takie przedefiniowanie działań renowacyjnych, które odmieniło powiązania między uczestnikami renowacji, umożliwiając zmianę tego, co społeczne. 


\section{Zakończenie}

Zarówno konserwatorzy, jak i modernizatorzy chcieliby przemawiać w imieniu dawnych budowli podczas dyskusji nad ich konserwacją oraz renowacją (Strike, 1994). Jednak w wielu przypadkach ignorują oni sprawczość budynków, nie uwzględniając różnorodności innych bytów wprawionych w ruch na scenie renowacji i konserwacji. Podliczając aktorów ludzkich i pozaludzkich uczestniczących w renowacji Alte Aula w Wiedniu, zajęłam się dynamiką tego procesu. Analizowałam bogactwo repertuaru działań budynku: jego uległość, posłuszeństwo, sprzeciw oraz opór. Będąc sytuacją eksperymentalną, renowacja pozwoliła nam doświadczyć obiektywności siedemnastowiecznego budynku, która nie odnosiła się do żadnej konkretnej jakości jego struktury, żadnej Originalsubstanz w rozumieniu tradycyjnych badań nad konserwacją. Polegała ona natomiast na działaniu aktora, który okazał się „,zdolny” do przeciwstawienia się temu, co zapisano na temat jego historii w archiwach. Potrafił on przeciwstawić się temu, co zostało zrobione z jego strukturą podczas szeregu interwencji. Sytuacja renowacji jest wyjątkowa. Budynki mogą tu zmieniać swój sposób istnienia (od pośrednika do mediatora i z powrotem do pośrednika). Dopóki nie dojdzie do stabilizacji, budynki mogą wprowadzić wiele zamieszania w starania architektów i klientów mających na celu uzyskanie pełnej kontroli nad procesem przekształcania budynków zgodnie z uprzednio założonym scenariuszem.

\section{Podziękowania}

Pragnę podziękować Marcie Ries oraz Goergowi Traska za ich uczestnictwo w projekcie Gallery of Research w Wiedniu. Bardzo dziękuję również Sampsie Hyysalo za jego cenny wkład intelektualny i redakcyjny.

Publikacja za zgodą właścicieli praw do tekstu.

\section{Bibliografia}

Aibar E., Bijker, W. (1997). Constructing a City: The Cedra Plan for the Extension of Barcelona, Science, Technology \& Human Values, 22(1), 3-30.

Appleyard, D. (red.) (1979). The Conservation of European Cities. Cambridge, MA: MIT Press.

Blau, J. (1984). A Sociological Perspective on Architectural Practice. Cambridge, MA: MIT Press.

Bonnet, M. (red.) (1997). L'élaboration des projets architecturaux et urbains en Europe. Plan Construction et Architecture. Paris, Francja: PUCA.

Boudon, P. (1992). Introduction à l'architecturologie. Paris, Francja: Dunod.

Brand, S. (1994). How Buildings Learn. What Happens After They're Built. New York, NY: Viking. 
Broadbent, G. (1973). Design in Architecture: Architecture and the Human Sciences. London, UK: John Wiley \& Sons.

Bucciarelli, L. (1994). Designing Engineers, Cambridge, MA: MIT Press.

Callon, M. (1996). Le travail de la conception en architecture, Situations Les Cahiers de la recherche architecturale, 37, 25-35.

Callon, M. (1997). Concevoir: modele hiérarchique et modèle négocié. W M. Bonnet (red.), L'élaboration des projets architecturaux et urbains en Europe: Plan Construction et Architecture. Paris, Francja: PUCA.

Champy, F. (2001). Sociologie de l'architecture. Paris, Francja: La Découverte.

Cuff, D. (1991). Architecture: The Story of Practice. Cambridge, MA: MIT Press.

Dehio, G., Riegl, A., (1988). Konservieren, nicht restaurieren. Streitschriften zur Denkmalpflege um 1900. Braunschweig, Niemct: Vieweg.

Ferguson, E. (1992). Engineering and the Mind's Eye. Cambridge, MA: MIT Press.

Galison, P., Thompson, E. (red.) (1999). The Architecture of Science, Cambridge, MA: MIT Press.

Garfinkel, H. (1985). Studies in Ethnomethodology. Cambridge, UK: Polity Press.

Gieryn, T. (1999). Two Faces on Science: Building Identities for Molecular Biology and Biotechnology. W: P. Galison., E. Thompson. (red.), The Architecture of Science (s. 423-459). Cambridge, MA: MIT Press.

Gieryn, T. (2002). What Buildings Do. Theory and Society, 31, 35-74.

Gomart, E., Hennion, A., (1999). A sociology of attachment: music amateurs, drug users. W J. Law, J. Hassard (red.), Actor Network Theory and After (s. 220-248). London, UK: Blackwell Publishing.

Graham, S., Trift, N., (2007). Out of Order: Understanding Repair and Maintenance, Theory, Culture \& Society, 24(1), 1-25.

Hamann, G., Mühlberger, K., Skacel, F. (red.). (1985). Das Alte Universitätsviertel in Wien, 13851985, Vol. 2. Wien, Austria: Universität Wien.

Henderson, K. (1999). On Line and On Paper. Visual Representations, Visual Culture, and Computer Graphics in Design Engineering. Cambridge, MA: MIT Press.

Hennion, A. (1993). La Passion musicale. Une sociologie de la médiation. Paris, Francja: Métailié.

Hommels, A. (2005). Unbuilding Cities. Obduracy in Urban Sociotechnical Change. Cambridge, MA: MIT Press.

Houdart, S. (2006). Des multiples manières d'être reel. Les représentations en perspective dans le projet d'architecture, Terrain, 46, 107-122.

Jones, Ch. (1970). Design Methods: Seeds of Human Futures. London, UK: John Wiley \& Sons Ltd.

Knorr-Cetina, K. (1999). Epistemic Cultures: How the Sciences Make Knowledge. Cambridge, MA: Harvard University Press. 
Latour, B. (1987). Science in Action: How to Follow Scientists and Engineers Through Society. Cambridge MA: Harvard University Press.

Latour, B. (1999). On Recalling ANT. W J. Law, J. Hassard (red.), Actor Network Theory and After. Oxford, UK: Blackwell.

Latour, B. (2005). Reassembling the Social: an Introduction to Actor-Network-Theory. Oxford, UK: Oxford University Press.

Latour, B., Callon, M. (red.). (1982). La Science telle qu'elle se fait. Une anthologie de la sociologie des sciences de langue anglaise. Paris, Francja: Pandore.

Latour, B., Woolgar, S. (1979). Laboratory Life: the Social Construction of Scientific Facts. Beverly Hills, CA: Sage Publications.

Lebahar, J-Ch. (1983). Le dessin d'architecte: simulation graphique et réduction d'incertitude. Roquevaire, Francja: Parenthèses.

Livingston, D. (2003). Putting Science in its Place: Geographies of Scientific Knowledge. Chicago, IL: Chicago University Press.

Lynch, M. (1985). Discipline and the Material Form of Image: An Analysis of Scientific Visibility. Social Studies of Science, 15, 37-66.

McLean, Ch., Hassard, J. (2004). Symmetrical Absence/Symmetrical Absurdity: Critical Notes on the Production of Actor-Network Accounts, Journal of Management Studies, 41(3), 493-519.

Mühlberger, K. (red.) (1993). Aspekte der Bildungs- und Universitätsgeschichte. Vienna, Austria: Universitäts-Verlag.

Mukerji, Ch. (1997). Territorial Ambitions and the Gardens of Versailles. Cambridge, UK: Cambridge University Press.

Pickard, R. (red.). (2001). Management of Historic Centres. London, UK: Taylor \& Francis.

Picon, A., Ponte, A., Lerner, R. (red.). (2003). Architecture and the Sciences Exchanging Metaphors. New York, NY: Princeton Architectural Press.

Prost, R. (1999). Les pratiques architecturales en mutation. Les cahiers de la recherche architecturale: Métiers, 2-3, 85-94.

Raynaud, D. (2001). Compétences et expertise professionnelle de l'architecte dans le travail de conception. Sociologie du Travail, 43(4), 451-469.

Rheinberger, H-J. Towards History of Epistemic Things: Synthesising Proteins in the Test Tube. Stanford, CA: Stanford University Press.

Rowe, P. (1987). Design thinking. Cambridge, MA: MIT Press.

Ruskin, J. (1989). The Seven Lamps of Architecture. New York, NY: Dover Publications.

Schön, D. (1988). Educating the Reflective Practitioner. San Francisco, CA: Jossey-Bass Publishers.

Stengers, I., Prygogine, I. (1988). Entre le temps et l'éternité. Paris, Francja: Fayard.

Strike, J. (1994). Architecture in Conservation. Managing Development at Historic Sites. London, UK: Routledge. 
Traska, G. (2006). Designing renovation: the building as planning material. Building Research \& Information, 35(1), s. 54-69.

Vincenti, W. (1990). What Engineers Know and How They Know It: Analytical Studies from Aeronautical History. Baltimore, MD: Johns Hopkins University Press.

Vinck, D. (red). (2003). Everyday Engineering: an Ethnography of Design and Innovation. Cambridge, MA: MIT Press.

Yaneva, A. (2005). Scaling Up and Down: Extraction Trials in Architectural Design, Social Studies of Science, 35(6), 867-894.

\title{
How Buildings 'Surprise': The Renovation of the Alte Aula in Vienna
}

\begin{abstract}
Can old buildings faithfully transmit social meaning? Conservation studies have taught us for decades that buildings are valuable for their historical substance and symbolic value gradually acquired with time. Drawing on an Actor-Network-Theory-inspired perspective to tackle buildings, this article questions the philosophy of preservation studies and their definitions of building and agency. Following the process of renovation of the $17^{\text {th }}$ century Alte Aula in Vienna, I explore its dynamics and unpredictable drifts. Renovating is not about transforming a passive and subservient object; it rather offers an experimental situation in which one can witness the building recalcitrance, i.e., its capacity to manifest itself as disobedient as possible to the protocol of renovation, to resist the attempts of control and to 'surprise' its makers. A building is, I argue here, a complex mediator that skilfully redistributes the agency among human and nonhuman participants in renovation, provokes contextual mutations and transforms social meanings.
\end{abstract}

Keywords: renovation; ethnography; building agency; ANT; architecture. 